\title{
Effects of National and International Scout Camps on Some Daily Life Skills of Boy Scouts: Comparative Study
}

\author{
Amany Mohamed Al-Safty ${ }^{1}$ \\ ${ }^{1}$ Assistant professor - Department of Sports Recreation - Faculty of Physical Education - Tanta University - Egypt.
}

\begin{abstract}
The current research aims to identify the effects of national and international scout camps on improving daily life skills for boy scouts. Participants of this research are all boy scouts participating in Shobra Qass scout camp (national camp) $(n=20)$ and Rodney scout camp - Maryland - USA (international camp) $(n=20)$ during 2015. Those participants were purposefully chosen with an age group of (12-15) years. The researcher developed and calibrated the Daily Life Skills Scale for Boy Scouts. Results indicated statistically significant differences between national and international camps on the results of the daily life skills scale with improvement percentage of (10.04\%) in favor of international camps. In addition, improvement percentages for communication, negotiation, decision making and problem solving and stress management were $14.78 \%, 10.89 \%, 10.79 \%$ and $5.05 \%$ respectively in favor of international camps. Furthermore, international camps have positive effects on the acquisition of daily life skills by boy scouts.
\end{abstract}

Keywords: communication - decision making and problem solving - negotiation - stress management

\section{Introduction:}

$\mathrm{T}$ The whole society benefits greatly from individuals' good use of leisure time. If individuals have more leisure time without good means for using it, this will lead to various factors demolishing and corrupting the society. Recognizing the usefulness of leisure time is a great benefit for humanity but not organizing its use creates several problems that will lead to wasting this benefit in vain (Al-Samannoudy 2003).

Camps represent an educational method as it develops individuals through training youth on investing their leisure time effectively and usefully. Scout camps are important recreational activities as it provides natural opportunities for individuals to get involved in a simple environment to renovate life. Camps aim to teach health life style and risk prevention in addition to good use of leisure time and improve individual's character through democratic life and emotional education (Abd El-Salam 2001).

Life is a series of changing unclear situations. Therefore, it is completely different from the content of academic curricula with their clear situations that can be solved through rules of engagement with the variables of ever changing and ever evolving environment. So, it is important to provide individuals with necessary daily life skills to be used in their activities and to enable them with face continuous life changes. Price (2007) indicated that daily life skills enable individuals to use their energy positively as some of the individuals' negative behaviors result from their inability to use their energy positively. This may lead them to smoking, drug abuse, violence and law violation. Such behaviors affect their relations with their families, peers, and the whole society. Meary (2005) indicated that these skills enable individuals to selfdevelop themselves as it makes them feel more selfappreciation which is vital for avoiding serious problems like depression, loneliness, hurt, crime and decreased academic achievement.

Carson \& Runco (1999) indicated that acquiring daily life skills enables individuals to solve problems and be more adaptive to reality in addition to managing life stress. It makes them more effective in dealing with a competitive reality for job opportunities, economic changes and cultural and social transformations. Megel et al (1994) indicated that if individuals do not acquire daily life skills they become unable to fulfill the tasks required during their age stages.

Nowadays, the world is witnessing major increase in knowledge and rapprochement in addition to the information and communication revolution. These factors affected the evolution of educational thinking. Therefore, 
individuals should acquire daily life skills necessary for fulfilling the educational objectives of preparing good citizens who is adaptive to local and international communities and who is able to bear responsibilities and face the challenges of this modern age through positive social reaction to life. This makes individuals more able to fulfill their duties towards their families and societies in addition to earning their rights.

Hefter et al (2014), Abadi \& Foudini (2014), Gomes \& Mraques (2013) and Al-Safty \& Al-Shebiny (2006) indicated that improving these skills is not limited to a specific educational stage. Instead, it covers all stages. In addition, students and teachers should gain sufficient amount of these skills to practice them as they help fulfilling the students' needs for belonging to a group and making meaningful relations with others. Students learn problem solving, responsibility bearing, decision making and valuing skills as these skills enable them to active participation and sense of national belonging. It provides individuals with values, principles and trends of the society. Therefore, it works on developing the individual's spiritual, ethical, intellectual, physical, behavioral and social aspects. The ultimate goal of education is to achieve integrated development of all aspects of the individual and to help him/her to coexist with self and external world. These skills are also important because they generate good feelings continuously and this has positive effects on coexisting with life and facing its problems. Daily life skills are required for managing life as they help the individual to be independent in facing challenges and bearing responsibilities in addition to achieving satisfaction.

Ulhs et al (2014) and Westberg (2013) indicated that the international Boy Scout movement encourages crosscultural and cross-geographic meetings as it facilitates such meetings among members all over the world. Leisure time is the time for acquiring social and educational skills, values and experiences. During that time, individuals can satisfy their hobbies, attitudes and needs in addition to improving creativity and renovation. This helps achieving psychological balance and improving the individual's character. Scout camps programs try to rise the upcoming generation through increasing awareness of using leisure time in a beneficial way for the individual and the society as well. These camps provide individuals with opportunities to participate in various activities during leisure time.

Mills (2013) and Jago et al (2006) indicated that daily life skills in scout camps provide individuals with selfconfidence and make them more able to interact with others and to effectively enact self-management. This makes individual active participants in local and international communities in addition to dealing with situations they face in an educational environment with specific context. The researcher thinks that scout camps satisfy the individual's needs for organizing leisure time. It is an environment rich with its programs for improving daily life skills positively. According to the researcher's knowledge, there were no previous studies dealing with the role of national and international camps in improving daily life skills for boy scouts.

The current research aims to identify the effects of national and international scout camps on improving daily life skills for boy scouts. The researcher hypothesized that there are no statistically significant differences between national and international scout camps on improving daily life skills for boy scouts.

\section{Materials \& Methods:}

\section{Approach:}

The researcher used the descriptive approach for comparing the two groups at the end of each scout camp.

\section{Participants:}

Participants of this research are all boy scouts participating in Shobra Kas scout camp (national camp) $(n=20)$ and Rodney scout camp - Maryland - USA (international camp) $(n=20)$ during 2015. Those participants were purposefully chosen with an age group of (12-15) years. Another (20) boy scouts from outside the main sample were chosen as a pilot sample for calibrating the daily life skills scale. Tables (1) and (2) showed homogeneity and moderation of data for participants. 
Table (1)

Statistical significance for participants on the daily life skills scale $(n=40)$

\begin{tabular}{|c|c|c|c|c|c|c|}
\hline & Axes & Measurement & Mean & Median & SD & Squewness \\
\hline 1 & Communication & Point & 19.53 & 19.00 & 2.74 & 0.57 \\
\hline 2 & Decision making \& Problem solving & Point & 15.00 & 14.00 & 2.51 & 1.20 \\
\hline 3 & Negotiation & Point & 11.50 & 12.00 & 2.17 & -0.69 \\
\hline 4 & Stress management & Point & 24.85 & 25.00 & 3.12 & -0.14 \\
\hline- & Total & Point & 70.88 & 71.00 & 5.62 & -0.07 \\
\hline
\end{tabular}

Table (1) indicated that squewness values were between $( \pm 3)$. This indicates that data is free of radical distributions.

Table (2)

Difference significance participants on the daily life skills scale $(\mathrm{n} 1=\mathrm{n} 2=20)$

\begin{tabular}{|c|c|c|c|c|c|c|c|c|c|}
\hline & \multirow{2}{*}{$\begin{array}{c}\text { Axes } \\
\text { Communication }\end{array}$} & \multirow{2}{*}{$\begin{array}{l}\text { Measurement } \\
\text { Point }\end{array}$} & \multicolumn{2}{|c|}{$\begin{array}{l}\text { National camp } \\
\quad(\mathrm{n} 1=20)\end{array}$} & \multicolumn{2}{|c|}{$\begin{array}{l}\text { International camp } \\
(\mathrm{n} 2=20)\end{array}$} & \multirow{2}{*}{$\begin{array}{c}\text { Means } \\
\text { difference }\end{array}$} & \multirow{2}{*}{$\mathrm{F}$} & \multirow{2}{*}{$\mathrm{T}$} \\
\hline & & & Mean & $\mathrm{SD}$ & Mean & $\mathrm{SD}$ & & & \\
\hline 1 & Communication & Point & 19.40 & 1.66 & 19.65 & 1.73 & 0.25 & 1.09 & 0.45 \\
\hline 2 & $\begin{array}{l}\text { Decision making \& Problem } \\
\text { solving }\end{array}$ & Point & 15.10 & 1.54 & 14.90 & 1.29 & 0.20 & 1.67 & 0.43 \\
\hline 3 & Negotiation & Point & 11.35 & 1.37 & 11.65 & 1.44 & 0.30 & 1.10 & 0.65 \\
\hline 4 & Stress management & Point & 24.60 & 1.89 & 25.10 & 1.72 & 0.50 & 1.21 & 0.72 \\
\hline- & Total & Point & 70.45 & 3.31 & 71.30 & 3.43 & 0.85 & 1.07 & 0.77 \\
\hline
\end{tabular}

F table value on $\mathrm{P} \leq 0.05$ and freedom degrees of $(19,19)=2.15$

$\mathrm{T}$ table value on $\mathrm{P} \leq 0.05=2.02$

Table (2) indicated that $f$ calculated values were lower than its table value. This indicates that the two groups are homogeneous.

\section{Data collection tools:}

\section{The Daily Life Skills Scale}

The researcher prepared the scale according to the following steps:

1- Review of related literature including Hefter et al (2014), Abadi \& Foudini (2014), Gomes \& Mraques (2013), Ulhs et al (2014) and Al-Safty \& Al-Shebiny (2006).

2- The researcher identified some recommended axes of daily life skills through identifying experts' opinions and review of literature.
3- The researcher formulated the preliminary version of the axes

4- The researcher presented the preliminary version of the axes on experts

5- The researcher formulated the preliminary version of the items

6- The researcher presented the preliminary version of the items on experts then calculated validity and reliability of the scale.

The researcher calculated logical validity of the scale through presenting it to (30) experts who were faculty members of faculties of physical education and experts in sports recreation. Table (3) shows experts' opinions about the scales axes. 
Table (3)

Frequency and percentage of experts' opinions about the axes of daily life skills scale for boy scouts $(\mathrm{n}=30)$

\begin{tabular}{|c|c|c|c|c|c|c|c|}
\hline \multirow{2}{*}{ Daily life skills } & \multicolumn{2}{|c|}{ Agree } & \multicolumn{2}{c|}{ Disagree } & \multirow{2}{*}{ Relative weight } & \multirow{2}{*}{ Relative importance } \\
\cline { 2 - 6 } & Frequency & $\%$ & Frequency & $\%$ & & 96.67 \\
\hline & Communication & 29 & 96.67 & 1 & 3.33 & 29.00 & 73.33 \\
\hline & Cooperation and team work & 22 & 73.33 & 8 & 26.67 & 22.00 & 93.33 \\
\hline & Negotiation & 28 & 93.33 & 2 & 6.67 & 28.00 & 26.67 \\
\hline & Self-management & 8 & 26.67 & 22 & 73.33 & 8.00 & 96.67 \\
\hline & Decision making \& Problem solving & 29 & 96.67 & 1 & 3.33 & 29.00 & 66.67 \\
\hline & Critical thinking & 20 & 66.67 & 10 & 33.33 & 20.00 & 93.33 \\
\hline & Stress management & 28 & 93.33 & 2 & 6.67 & 28.00 & 46.67 \\
\hline
\end{tabular}

Table (3) indicated that percentages of agreement on axes of the scale ranged from $26.67 \%$ to $96.67 \%$. All axes gaining less than $90 \%$ of agreement were omitted.

Table (4)

Frequency and percentage of experts' opinions about the items of daily life skills scale for boy scouts $(\mathrm{n}=30)$

\begin{tabular}{|c|c|c|c|c|c|c|c|}
\hline \multicolumn{2}{|c|}{ Communication } & \multicolumn{2}{|c|}{ Decision making \& Problem solving } & \multicolumn{2}{|r|}{ Negotiation } & \multicolumn{2}{|c|}{ Stress management } \\
\hline Item & Agreement $(\%)$ & Item & Agreement $(\%)$ & Item & Agreement (\%) & Item & Agreement (\%) \\
\hline 1 & 56.67 & 1.00 & 80.00 & 1 & 100.00 & 1 & 36.67 \\
\hline 2 & 100.00 & 2.00 & 96.67 & 2 & 100.00 & 2 & 56.67 \\
\hline 3 & 96.67 & 3.00 & 100.00 & 3 & 76.67 & 3 & 100.00 \\
\hline 4 & 100.00 & 4.00 & 100.00 & 4 & 76.67 & 4 & 90.00 \\
\hline 5 & 100.00 & 5.00 & 93.33 & 5 & 86.67 & 5 & 90.00 \\
\hline 6 & 76.67 & 6.00 & 80.00 & 6 & 53.33 & 6 & 86.67 \\
\hline 7 & 96.67 & 7.00 & 66.67 & 7 & 80.00 & 7 & 93.33 \\
\hline 8 & 93.33 & 8.00 & 46.67 & 8 & 100.00 & 8 & 60.00 \\
\hline 9 & 86.67 & 9.00 & 96.67 & 9 & 93.33 & 9 & 90.00 \\
\hline 10 & 83.33 & 10.00 & 93.33 & 10 & 90.00 & 10 & 76.67 \\
\hline 11 & 93.33 & 11.00 & 100.00 & & & 11 & 100.00 \\
\hline 12 & 100.00 & 12.00 & 63.33 & & & 12 & 93.33 \\
\hline 13 & 100.00 & 13.00 & 60.00 & & & 13 & 76.67 \\
\hline & & & & & & 14 & 76.67 \\
\hline & & & & & & 15 & 100.00 \\
\hline & & & & & & 16 & 46.67 \\
\hline & & & & & & 17 & 43.33 \\
\hline & & & & & & 18 & 100.00 \\
\hline
\end{tabular}

Table (4) indicated that percentages of agreement on items of the scale ranged from $36.67 \%$ to $100 \%$. All items gaining less than $76.67 \%$ of agreement were omitted. 
Table (5)

Omitted and modified items of the questionnaire

\begin{tabular}{|c|c|c|c|c|c|c|c|}
\hline & Daily life skills & $\begin{array}{c}\text { Number of } \\
\text { preliminary skills }\end{array}$ & $\begin{array}{c}\text { Number of } \\
\text { excluded items }\end{array}$ & $\begin{array}{l}\text { Excluded } \\
\text { items }\end{array}$ & $\begin{array}{c}\text { Number of } \\
\text { modified items }\end{array}$ & $\begin{array}{l}\text { Modified } \\
\text { items }\end{array}$ & $\begin{array}{l}\text { Final number } \\
\text { of items }\end{array}$ \\
\hline 1 & Communication & 13 & 1 & 7 & - & - & 12 \\
\hline 2 & $\begin{array}{l}\text { Decision making \& } \\
\text { Problem solving }\end{array}$ & 13 & 3 & $7 \cdot 8 \cdot 13$ & 4 & $\begin{array}{c}6 \cdot 9 \cdot 10 ، \\
11\end{array}$ & 10 \\
\hline 3 & Negotiation & 10 & 1 & 6 & 1 & 9 & 9 \\
\hline 4 & Stress management & 18 & 5 & $\begin{array}{l}1 ، 2 ، 8 \\
، 16 ، 17\end{array}$ & 3 & 12 ، $13 ، 14$ & 13 \\
\hline & Total & 54 & 10 & - & 8 & - & 44 \\
\hline
\end{tabular}

Table (5) indicated that experts omitted (10) items and To calculate internal consistency, the researcher applied modified (8) items. The final number of items was reduced the scale to a pilot sample ( $\mathrm{n}=20)$ and calculated from (54) to (44) items. correlation coefficient between each item and its axis and each item and total score as seen in table (6) and (7).

Table (6)

Internal consistency between each item and its axis and each item and total score $(n=20)$

\begin{tabular}{|c|c|c|c|c|c|c|c|c|c|c|c|}
\hline \multicolumn{3}{|c|}{ Communication } & \multicolumn{3}{|c|}{$\begin{array}{l}\text { Decision making \& Problem } \\
\text { solving }\end{array}$} & \multicolumn{3}{|c|}{ Negotiation } & \multicolumn{3}{|c|}{ Stress management } \\
\hline Item & $\begin{array}{c}\text { Item with } \\
\text { axis }\end{array}$ & $\begin{array}{l}\text { Item with } \\
\text { total }\end{array}$ & Item & Item with axis & Item with total & Item & $\begin{array}{c}\text { Item with } \\
\text { axis }\end{array}$ & $\begin{array}{l}\text { Item with } \\
\text { total }\end{array}$ & Item & $\begin{array}{l}\text { Item with } \\
\text { axis }\end{array}$ & $\begin{array}{l}\text { Item with } \\
\text { total }\end{array}$ \\
\hline 1 & 0.71 & 0.62 & 1 & 0.67 & 0.61 & 1 & 0.64 & 0.58 & 1 & 0.69 & 0.58 \\
\hline 2 & 0.65 & 0.74 & 2 & 0.61 & 0.72 & 2 & 0.65 & 0.72 & 2 & 0.71 & 0.64 \\
\hline 3 & 0.76 & 0.66 & 3 & 0.86 & 0.72 & 3 & 0.72 & 0.68 & 3 & 0.74 & 0.61 \\
\hline 4 & 0.68 & 0.61 & 4 & 0.72 & 0.82 & 4 & 0.59 & 0.64 & 4 & 0.59 & 0.63 \\
\hline 5 & 0.61 & 0.89 & 5 & 0.63 & 0.72 & 5 & 0.74 & 0.83 & 5 & 0.72 & 0.67 \\
\hline 6 & 0.59 & 0.64 & 6 & 0.85 & 0.77 & 6 & 0.57 & 0.61 & 6 & 0.65 & 0.72 \\
\hline 7 & 0.70 & 0.68 & 7 & 0.60 & 0.67 & 7 & 0.63 & 0.70 & 7 & 0.77 & 0.71 \\
\hline 8 & 0.81 & 0.78 & 8 & 0.64 & 0.54 & 8 & 0.62 & 0.71 & 8 & 0.62 & 0.69 \\
\hline 9 & 0.64 & 0.58 & 9 & 0.66 & 0.72 & 9 & 0.71 & 0.52 & 9 & 0.81 & 0.76 \\
\hline 10 & 0.72 & 0.81 & 10 & 0.78 & 0.81 & & & & 10 & 0.74 & 0.68 \\
\hline 11 & 0.66 & 0.73 & & & & & & & 11 & 0.66 & 0.73 \\
\hline \multirow[t]{2}{*}{12} & 0.68 & 0.63 & & & & & & & 12 & 0.58 & 0.64 \\
\hline & & & & & & & & & 13 & 0.65 & 0.71 \\
\hline
\end{tabular}

$\mathrm{R}$ table value on $\mathrm{P} \leq 0.05=0.44$

Table (6) indicated statistically significant correlations between each item and its axis and each item and total score and this proves internal consistency of the scale. 
Table (7)

Internal consistency between each axis and total score $(\mathrm{n}=20)$

\begin{tabular}{|c|c|c|}
\hline & Daily life skills & $\mathrm{R}$ \\
\hline 1 & Communication & $0.68 *$ \\
\hline 2 & Decision making \& Problem solving & $0.71^{*}$ \\
\hline 3 & Negotiation & $0.74 *$ \\
\hline 4 & Stress management & $0.69 *$ \\
\hline
\end{tabular}

$\mathrm{R}$ table value on $\mathrm{P} \leq 0.05=0.44$

Table (7) indicated statistically significant correlations between each axis and total score and this proves internal consistency of the scale.

To calculate reliability, the researcher used test/retest procedure on a pilot sample $(n=20)$ with fifteen-day time interval between test and retest as seen in tables (8) and (9).

Table (8)

Correlation coefficient between test and retest for reliability of the scale $(n=20)$

\begin{tabular}{|c|c|c|c|c|c|c|c|}
\hline \multicolumn{2}{|c|}{ Communication } & \multicolumn{2}{c|}{ Decision making \& Problem solving } & \multicolumn{2}{c|}{ Negotiation } & \multicolumn{2}{c|}{ Stress management } \\
\hline Item & $\mathrm{R}$ & $\mathrm{Item}$ & $\mathrm{R}$ & $\mathrm{Item}$ & $\mathrm{R}$ & $\mathrm{Item}$ & $\mathrm{R}$ \\
\hline 1 & $0.74^{*}$ & 1 & $0.71^{*}$ & 1 & $0.69^{*}$ & 1 & $0.81^{*}$ \\
\hline 2 & $0.63^{*}$ & 2 & $0.87^{*}$ & 2 & $0.68^{*}$ & 2 & $0.77^{*}$ \\
\hline 3 & $0.87^{*}$ & 3 & $0.75^{*}$ & 3 & $0.80^{*}$ & 3 & $0.76^{*}$ \\
\hline 4 & $0.84^{*}$ & 4 & $0.70^{*}$ & 4 & $0.73^{*}$ & 4 & $0.87^{*}$ \\
\hline 5 & $0.76^{*}$ & 5 & $0.64^{*}$ & 5 & $0.67^{*}$ & 5 & $0.69^{*}$ \\
\hline 6 & $0.68^{*}$ & 6 & $0.69^{*}$ & 6 & $0.72^{*}$ & 6 & $0.72^{*}$ \\
\hline 7 & $0.80^{*}$ & 7 & $0.60^{*}$ & 7 & $0.86^{*}$ & 7 & $0.59^{*}$ \\
\hline 8 & $0.83^{*}$ & 8 & $0.67^{*}$ & 8 & $0.69^{*}$ & 8 & $0.66^{*}$ \\
\hline 9 & $0.74^{*}$ & 9 & $0.81^{*}$ & 9 & $0.85^{*}$ & 9 & $0.74^{*}$ \\
\hline 10 & $0.80^{*}$ & 10 & $0.69^{*}$ & & & 10 & $0.67^{*}$ \\
\hline 11 & $0.64^{*}$ & & & & & 11 & $0.69^{*}$ \\
\hline 12 & $0.73^{*}$ & & & & & 12 & $0.70^{*}$ \\
\hline & & & & & & 13 & $0.67^{*}$ \\
\hline
\end{tabular}

$R$ table value on $\mathrm{P} \leq 0.05=0.44$

Table (8) indicated statistically significant correlations between test and retest. These correlations ranged from 0.59 to 0.87 which are higly significant indicating the reliability of the scale.

Table (9)

Cronbach's Alpha of the four axes of the scale $(n=20)$

\begin{tabular}{|c|c|c|}
\hline \multicolumn{2}{|c|}{ Cronbach's Alpha } \\
\hline \multicolumn{2}{|c|}{0.768} \\
\hline 1 & Daily life skills & Cronbach's Alpha if Item Deleted \\
\hline 2 & Communication & 0.762 \\
\hline 3 & Decision making \& Problem solving & 0.754 \\
\hline 4 & Negotiation & 0.761 \\
\hline
\end{tabular}

Table (9) indicated that Cronbach's Alpha values for the four axes are high indicating the scale's reliability.

Application of the daily life skills scale for boy scouts:
After fulfilling all scientific and administrative requirements, the researcher applied the scale during the 
first week after the camp at ALSALAM Scouts Group Tanta, according to the following steps:

- The scale was applied individually

- All participants were assured of the importance of their responses and were instructed to choose only one response for each item.

- All participants were instructed to read the scale well before responding

- All participants were assured that their responses will only be used for scientific purposes and will not be revealed to any third party

Table (10)

Difference significance and improvement percentages of participants' responses for the daily life skills scale for boy scouts $(\mathrm{n} 1=\mathrm{n} 2=$ 20)

\begin{tabular}{|c|c|c|c|c|c|c|c|c|}
\hline & \multirow{2}{*}{ Daily life skills } & \multicolumn{2}{|c|}{ National camp } & \multicolumn{2}{|c|}{ International camp } & \multirow{2}{*}{ Means difference } & \multirow{2}{*}{$\mathrm{T}$} & \multirow{2}{*}{ Improvement (\%) } \\
\cline { 2 - 7 } & Mean & SD & Mean & SD & & & \\
\hline 1 & Communication & 25.950 & 1.470 & 30.450 & 2.890 & 4.500 & $6.20^{*}$ & 14.780 \\
\hline 2 & Decision making \& Problem solving & 20.250 & 1.210 & 22.700 & 1.130 & 2.450 & $6.63^{*}$ & 10.790 \\
\hline 3 & Negotiation & 17.600 & 1.100 & 19.750 & 1.020 & 2.150 & $6.43^{*}$ & 10.890 \\
\hline 4 & Stress management & 33.850 & 1.180 & 35.650 & 0.930 & 1.800 & $5.35^{*}$ & 5.050 \\
\hline- & Total & 97.650 & 2.060 & 108.550 & 3.750 & 10.900 & $11.40^{*}$ & 10.040 \\
\hline
\end{tabular}

(T) Table value on $\mathrm{P} \leq 0.05=1.68$

Table (10) indicated statistically significant differences between the two groups as $(\mathrm{t})$ calculated value was higher than its table value.

\section{Discussion:}

Results indicated positive effects of Boy Scout camps on improving daily life skills for individuals and strengthening social and cultural relations and good behavior for the group in addition to discovering and improving personal hobbies for boy scouts. Table (10) indicated statistically significant differences between national and international camps as $(\mathrm{t})$ calculated values ranged from 5.35 to 6.43 and a total score of 11.40 which are all higher than its table value (1.68). Improvement percentages ranged from $(5.05 \%)$ (Stress management) to (14.78\%) (Communication). These differences were in favor of international camps indicating that these camps has more positive effects on daily life skills compared to national camps.

This is consistent with Hefter et al (2014), Mills (2013), Gomes \& Mraques (2013), Ulhs et al (2014) and Al-Safty \& Al-Shebiny (2006) who indicated the positive effects of Boy Scout camps on daily life skills. These results clearly indicated that numerous camps were prepared for improving daily life skills of boy scouts as these camps

\section{Data correction and tabulation:}

Responses of participants were corrected according to a three-point correction key (Yes= $3-$ somehow $=2-\mathrm{No}=$ 1). Data was tabulated for statistical treatment.

\section{Statistical treatment:}

The researcher used SPSS software to calculate the following: mean - SD - percentage $(\%)$ - correlation coefficient $(\mathrm{R})-(\mathrm{T})$ value - Cronbach's Alpha.

\section{Results:}

establish the scouts' positive orientation of character through feeling, behaviors and models. This can be done through camps as camps are no longer places for merely leisure time. Instead, they are now a means for guiding individuals towards their daily life needs.

Camps are the core of scouts' work. Through camps, the Boy Scout can discover his skills, fulfill his self and trust his abilities. It prepares individuals to acquire practical experience in daily activities and general principles without any racial, gender or religious discrimination and according to the principles and concepts established by the founder of the boy scouts movement. The main aim of the boy scouts movement asserts the fat that it can never replace families, religious institutes or social organizations. Instead, it completes its educational effects according to the administrative system of the state. In fact, the state is a member of the international society and the good citizen should be aware of his rights and duties in various societies to which he belongs (Al-Shafee 2003).

Improvement percentages of "stress management" are higher than other skills during international camps. This is because the boy scouts in these caps is always under pressure and the various levels of stress have positive effects on boy scouts. Daily life skills include identifying stress and major problems that may cause stress if 
unsolved. This is why it is important to improve this particular skill positively (Vranda \& Rao 2011).

Communication skill improved greatly in international camps due to the presence of individuals from several nationalities and this helped scouts to form new relations with new peers. This proves the importance of international camps and its positive effects on daily life skills.

Vranda \& Rao (2011) indicated that personal relations help positively in connecting to others through interaction. In addition, the ability to form friendly relations with others is very vital for mental and social health. This means that the individual is capable of maintaining good relations with individuals who are the source of social support or even end such relations constructively.

Results indicated the importance of daily life skills for all individuals in the society as they are the main requirements needed by all individuals to be consistent with them and their society. They help individuals solve their daily life problems and interact with various life situations. Kumar \& Chhabra (2014) indicated that daily life skills are behaviors for problem solving and can be used effectively to manage individuals' life.it is a group of skills acquired through learning and direct experience. It is used to deal with problems facing individuals every day.

The researcher thinks that international camps can be used effectively to improve daily life skills for the boy scouts as these camps are places for acquiring such skills. In addition, international camps abroad can provide the Boy Scout with cognitive and living experiences that support their values and educational and social experiences like communication, forming relations with others, stress management, decision making and problem solving. This can be done in very interesting way through satisfying their hobbies and attitudes.

\section{Conclusions:}

According to this research aim, materials, methods and results, the researcher concluded the following:

- There are statistically significant differences between national and international camps on the results of the daily life skills scale with improvement percentage of (10.04\%) in favor of international camps.

- Improvement percentages for communication, negotiation, decision making and problem solving and stress management were $14.78 \%, 10.89 \%, 10.79 \%$ and $5.05 \%$ respectively in favor of international camps.
- International camps have positive effects on the acquisition of daily life skills by boy scouts.

\section{Recommendations:}

The researcher recommends the following:

- It is important to guide the Egyptians towards outdoor camps as a means for spending leisure time.

- Daily life skills necessary for the Boy Scout are communication, negotiation, decision making and problem solving and stress management.

- It is important to send more boy scouts to international camps due to its positive effects.

\section{References:}

1- Abadi, V., \& Goudini, F. (2014). Investigation of Relationship between 'Life Skills and Psychological Security'and 'Happiness'. Reef Resources Assessment and Management Technical Paper, 40(4), 1.

2- Abd El-Salam, Tahany (2001): Modern Management of Camps, PP: 26-29, Dar Al-Maaref - Cairo - Egypt (in Arabic)

3- Al-Safty, Amany \& Al-Shebiny, Sahar (2006): Effects of recreational games and motor stories on some daily life skills and verbal and numeric concepts of kindergarten children. Scientific Journal of Physical education and Sports. Faculty of Physical Education - Tanta University Egypt (in Arabic).

4- Al-Samannoudy, Mohamed (2003): Sports Recreation and Leisure Time. P: 11, Shagarat Al-Dor Press, Mansoura - Egypt (in Arabic)

5- Al-Shafey, Gamal El-Din (2003): Outdoor Education and Boy Scouts Movement. P: 9. Dar Al-Fikr Al-ArabyCairo - Egypt (in Arabic)

6- Carson, David, K. and Runco, Mark, A. (1999). 'Creative problem solving and problem finding in young adults. Interconnections with Stress. Hassles, and Coping Abilities', Journal of Creative Behavior 33 (3): 167-89.

7- Gomes, A. R., \& Marques, B. (2013). Life skills in educational contexts: testing the effects of an intervention programme. Educational Studies, 39(2), 156-166.

8- Hefter, M. H., Berthold, K., Renkl, A., Riess, W., Schmid, S., \& Fries, S. (2014). Effects of a training intervention to foster argumentation skills while processing conflicting scientific positions. Instructional Science, 42(6), 929-947. 
9- Jago, R., Baranowski, T., Baranowski, J. C., Thompson, D., Cullen, K. W., Watson, K., \& Liu, Y. (2006). Fit for Life Boy Scout badge: outcome evaluation of a troop and Internet intervention. Preventive medicine, 42(3), 181187.

10- Kumar, J., \& Chhabra, A.(2014) Life Skill Education for Adolescents: Coping with Challenges. SRJHS\&EL Vol. -I, ISSUE-II, 181 -190

11- Leary, M. (2005). Making sense of self-esteem. Annual Educations, Adolescent Psychology, (5/6), 32-34.

12- Megel, M., Wade F., Hawkins, P. (1994). Health promotion, self-esteem and weight among female college freshmen, Health Values 18(4), 10-19.

13- Mills, S. (2013). 'An instruction in good citizenship': scouting and the historical geographies of citizenship education. Transactions of the Institute of British Geographers, 38(1), 120-134.

14- Omran, Taghreed; Al-Shenawy, Ragaa \& Sobhy, Afaf (2001): Daily Life Skills, P: 9, Zahraa Al-Shark Library Cairo - Egypt (in Arabic)
15- Price, L. (2007). The biology of risk taking Annual Educations Adolescent Psychology, (5) 38-41.

16- Uhls, Y. T., Michikyan, M., Morris, J., Garcia, D., Small, G. W., Zgourou, E., \& Greenfield, P. M. (2014). Five days at outdoor education camp without screens improves preteen skills with nonverbal emotion cues. Computers in Human Behavior, 39, 387-392.

17- van der Heide, I., Wang, J., Droomers, M., Spreeuwenberg, P., Rademakers, J., \& Uiters, E. (2013). The relationship between health, education, and health literacy: results from the Dutch Adult Literacy and Life Skills Survey. Journal of health communication, 18(sup1), 172-184.

18- Vranda, M. N., \& Rao, M. C. (2011). Life skills education for young adolescents-Indian experience. Journal of the Indian Academy of Applied Psychology, 37(9), 9-15.

19- Westberg Broström, A. (2013). "Wild Scouts": Swedish Scouting Preparing Responsible Citizens for the Twenty-First Century. Child \& Youth Services, 34(1), 922. 
